\title{
The Value of Human Resource Flexibility: A Study of Private and Public Organisations in The Gambia
}

\author{
GIBRIEL BADJIE \\ School of Business \& Public Administration \\ University of The Gambia \\ MDI Road, Kanifing P.O. Box 3530, Serrekunda, The Gambia \\ Email: gbadjie@utg.edu.gm
}

Diterima 24 September 2020; disetujui 29 September 2020;

\begin{abstract}
Human resource flexibility has attracted lots of research attention, but limited papers categorically address the benefits of HR flexibility to employees. This paper is purposely crafted to address the knowledge gap and bridge the perception and expectation gap from both sides regarding the benefit of $H R$ flexibility. The research uses a mixed method approach. First used questionnaire-based survey, but and second interviewed 10 employees randomly selected from organisations that participate in the survey. About 80 senior HR personnel participated in the survey representing the views of 40 private and public organisations. A stratified random sampling technique was used using two organisation directories as sample frame. The outcome of the study discovers differences in the practice of HR flexibility between private and public organisations in the Gambia. The outcome also dictates that, the views expressed by the senior HR personnel cannot represent the position of the employees. HR flexibility has economic and social benefits for the organisation and employees, therefore further study is recommended to delve deep into the issues.
\end{abstract}

Keywords: Human Resource Flexibility, Strategic Human Resource Management, Human Resource Management, Private Organisation, Public Organisation

\section{INTRODUCTION}

Background. Today, the ability to determine organisational competence is largely dependent on an organisation's ability to provide flexibility as key in defining the productive outcome of the organisation from the perspective of strategic human resource management, (Wright \& Snell, 1998). The value of HR flexibility is measured largely to enhance the profit-making capability of the organisation in the midst of uncertainty and challenges through employment and employees. The essence of value in this study reflects the economic and social benefits accorded to both employer and employees in the chain of organisation-employee relationship. 
Organisational value is a mixed package, defined and measured based on how it serves the needs of those concern. Hence this research is contextualized in the Gambia between the private organisations and public organisations whose behaviour and approach to business orientations differs and value represents profits through performance. value in this study affects both employer and employees with different expectations and perception through their investments of effort, time and energy in the organisation.

HR flexibility as HRM concept aligned with many theories. HR flexibility saddled between, first strategic theories which is characterised by good fit between HR practice and the internal and external context of the organisation. Secondly, HR flexibility strongly leaned towards the contingency theory that looks at factors influenced by organisational environmental constrains (both inside and outside), congruent is key in contingency approach in terms of uncertainties and challenges. Today is identified as a strategic HRM concept that strategically epitomizes employees as the single most important factor for the continued survival of organisation as in line resource-based view (Barney, 2001).

The concept of HR flexibility features in many papers of HRM, Guest et al. (2003); and the practice of HR flexibility seems to have direct and inevitable impact on the management of people in organisations, (Bhattacharya, Gibson \& Doty, 2005). Human resource flexibility as a strategy contained practice and policy focus to demonstrate the special approach to the management of people for long-term mutual employment relationship and for cost cutting measures to enhance the bottom line of the organisation, (Carvalho \& Cabral-Cardoso, 2008).

The research takes an explanatory approach to establish value of HR flexibility in organisation for both private and public organisations in The Gambia. The two organisations are similar in the conduct of business for profit making but have different behavioural characteristics. Therefore, the purpose of this study is to focus on the benefits of HR flexibility in organisation and give a vivid picture how employers and employees differ in their perception and expectation of HR flexibility benefits both private and public organisations. This research reflects upon how work affect employees through HR flexibility by putting pressure willingly or unwillingly with benefits or without benefits. There is a lot of pressure and burden placed on employees in the modern day organisation engaging them through HR flexibility to support the organisation to register competitive advantage in moments of environmental uncertainty and disturbance. The call for flexibility requires sacrifice more from employees than the organisation, yet still compromising their personal, family and communal responsibilities and obligations. The study is objectively tasked to establish whether the institutionalization of HR flexibility mutually serves the interest of the organisation and that of the employees.

Research Question. RQ: What is the value of HR flexibility to both the employer and employee?

\section{LITERATURE}

HR Flexibility. Human resource flexibility is a means to enhance the competitiveness 
of the firm by reducing costs and increase productivity. The organisation's increase in competitiveness through greater flexibility of human resources allows it to prevail over others for a long period of time, Sheridan \& Conway (2001). Flexibility as a strategy centers on "securing lower labour cost, tighter controls, higher machine utilization, greater staff mobility and few interruptions and bottlenecks in production", (Blyton, 1992). HR flexibility should not only focus on the economic benefits for the organisation but social and economic benefits for the employees as well. Martinez-Sanchez et al. (2007), organisational flexibility can be a defensive response to manage uncertainties with flexible organisation, flexible work structure and resources. HR flexibility is about the organisation of work to create a fit and balance for both the organisation and employees.

According to Pfeffer et al. (1995), "achieving competitive success through people involves fundamentally altering how we think about workforce and employment relationship. It means achieving success by working with people, not by replacing them or limiting the scope of their activities. It entails seeing the workforce as a strategic advantage not just a cost to be minimized or avoided. " HR Flexibility is a concept that requires tripartite interaction among management, employees, and other assets / resources, (Martinez-Sanchez et al., 2007). Flexibility heavily relies on people than any other factors to gain sustainable competitive advantage, (Upton, 1995). Many research contributions agreed that, "in a dynamic business environment, firm performance depends jointly on the inherent flexibilities of resources available to the firm and on the firm's ability to apply those resources to alternative courses of action", (Hitt, Keats \& DeMarie, 1998; Ketkar \& Sett, 2009).

HR flexibility is a dynamic capability that facilitate an organisation's effort to rapidly respond to changing environments, thus creating value, (Bhattacharya, Gibson \& Doty, 2005). The proponents of strategic HRM recognised the need for the organisation to adopt and embrace flexibility into the context of organisations (McDuffie, 1995; Wright \& Snell, 1998). According to Grenier et al. (1997); Kalleberg, (2001), HR flexibility is divided into two i.e. internal and external flexibility. Internal flexibility involves efforts to increase the firm's ability to adjust to changing or enhancing circumstances through modification of the internal labour market or work organization. HR flexibility like numerical flexibility can be sought externally by changing the level of employment through hiring and firing, layoffs and recalls, the use of temporary, part-time or casual employees, or other means to determine the inflow or outflow of workers, (Martinez-Sanchez et al., 2007).

Coordination flexibility, as contract work positively relates to measures of firm performance. Also, resource flexibility dependence on knowledge-based workers is beneficial and profitable to firm performance, (Lepak, Takeuchi \& Snell, 2003). It is obvious that HR flexibility as strategy is profitable to the organisation and Ngo \& Loi (2008) acknowledged that employee behaviour flexibility and HR practice flexibility heavily relates to HR-related performance and market-related performance when mediated by culture of the organisation. External 
flexibility has a significant return-on sales. Also, external flexibility has a greater positive effect on business performance than in a business characterised by high internal flexibility (Roca-Puig et al., 2008).

According to Roca-Puig et al. (2008), in a business context, a firm characterised by high internal flexibility always leads to greater labor productivity than firms lower in internal flexibility. Organisations high in external flexibility significantly reduces return on sales, while firms with a lower internal labor flexibility reduces absenteeism and increases return on sales. According to MartinezSanchez et al. (2007), functional flexibility is related to job rotation and job enrichment or enlargement that makes the deployment of individual workers to become more adaptable to tasks or conditions.

Labour flexibility represents a paradigm shifts in working life, 'organisations changing their employment strategies away from traditional structures to reduce the size of the workforce, and transfer of certain tasks from full time permanent staff to part-time temporary staff, and or transfer of certain tasks from directly employed staff to agency workers or sub-contractors, and or reorganization of direct employees so that they can take on a wider range of tasks', (Fahlbeck, 1998). This trend can be a threat to labour union's power as it tends to reduce the influence of unions. Ketkar \& Sett, (2009), unionization of labor affect firm performance measures, HR outcomes and ability to influence the implementation of HR flexibility efforts.

According to Sheridan \& Conway (2001), flexibility has different meanings in different contexts which often leads to conflict for employers and employees. Flexibility for the organisation in a business context means reorganization of work to bring about efficiency and a decrease in costs. Flexibility to employees' concern family-friendly organisational work practices which enables workers to balance their work and non-work responsibilities, (Pandey \& Khare, 2013).

The concept of work-life balance is based on the notion that paid work roles and personal life roles should not be seen as opposing ends rather complementary effort for both organisation and employees, (Pandey $\&$ Khare, 2013). The way to achieve this, is to adopt an approach that is "conceptualized as a two-way process involving a consideration of the needs of employees as well as those of employers" (Traynor, 1999). Work-life balance inclusivity benefits both the organisation and employees in a mutually different way. According to Traynor (1999), work-life balance initiatives help to rebrand the organisation being employer of choice, promote organisational citizenship behaviour and support diversity challenge.

\section{RESEARCH METHOD}

Type of research. A mixed method approach used to obtain relevant information. Mixed method is useful for triangulation to enable to establish the true picture of the problem (Sekaran \& Bougie, 2016). Firstly, a questionnaire-based survey was applied with a total of 150 questionnaires distributed and 80 usable questionnaires were returned representing $53 \%$ response rate. The objective of the study is to give vivid explanation of the benefits of HR flexibility to employers and 
employees from private and public organisations.

Sample. A representative sample of 100 organisations, 50 for each, from a population of 136 organisations. The study used stratified random sampling with two organisations directories as sample frame. A total of 40 organisations fully participated, returning 80 questionnaires from Senior HR personnel.

Secondly, 10 employees were randomly selected for face-to-face interview from among the 40 participated organisations. A total of 8 employees from public organisations and 2 from private. The survey engaged organisations with a staff roll of 100 and counting within the Greater Banjul Area. Organisations with 100 employees or more are likely to have an established functioning HR department, (Ketkar \& Sett 2009). The controlled variables of the research; HR department report to the head of the organisation, HR department represented at board level, existence of a Staff Association (union) and Staff Association represented at board level. SPSS is the dominant tool for data analysis in the study.

\section{RESULTS AND DISCUSTION}

\section{Interpretation of the Control Variables} Private versus Public organisations. The essence of control variables as evident from table $\mathbf{1}$ is to establish how flexible is the organisation is in terms of how much attention is given to employment and employee issues through the department of human resource and the staff Association (Union). Many of the organisations that took part in the survey has their human resource department reporting directly to the head of the organisation.
About $90 \%$ of senior HR personnel agreed that the head of the department have a direct reporting role to the head of the organisation. Expert have agreed that department head directly reporting to the Boss, strengthen the bargaining position of the department, the head therefore, has clout and influence in advising management on ways to manage employees for the common good of all. Only $10 \%$ of the senior HR personnel reported in the negative. The result indicated that only $26 \%$ of the participants agreed that HRD is represented at board level, compared to $74 \%$ of negative response. The representation of the human resource department at board level clearly indicates that human resource and employment issues are strategically place at the heart of the organization. The survey results show that $79 \%$ of the organizations has a functioning and a recognized staff association (union), compared to $21 \%$ that reported in the negative. The recognition of the staff association by the management indicates that the employees are seen as key stakeholders in their efforts to complement the efforts of management to better the welfare of the employees. A small number of organizations 33\% affirms that staff Association has a representation at board level which is a huge stride and a morale booster to the employees' concerns compared to $67 \%$ negative response. The degree of unionization is likely to affect organisational performance through HR outcomes and also influence the organization's ability to implement HR flexibility initiatives as employees carry the burden of that responsibility, (Ketkar \& Sett, 2009). The difference between the organisations can be viewed from table 1 in terms of their tolerance level. 
Table 1

Comparison of Public/Private Approach HRD and Staff Association

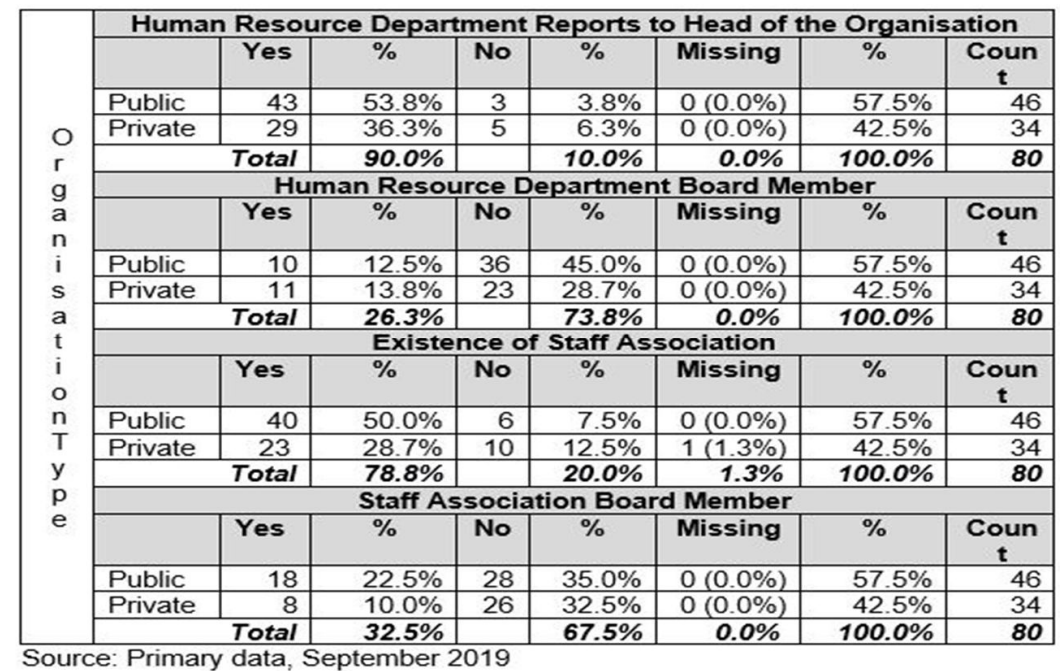

Table 2

Descriptive Statistics of HR Flexibility

\begin{tabular}{|c|c|c|c|c|c|c|c|}
\hline \multirow{2}{*}{$\begin{array}{l}\text { HR Flexibility } \\
\text { Dimensions }\end{array}$} & \multirow{2}{*}{ Mean } & \multicolumn{2}{|c|}{$\begin{array}{l}\text { Perception } \\
(\%)\end{array}$} & \multicolumn{2}{|c|}{ Private Org. } & \multicolumn{2}{|c|}{ Public org. } \\
\hline & & + & - & + & - & + & - \\
\hline Emp. Skill Flex. & 5.767 & 89 & 11 & 84 & 16 & 94 & 6 \\
\hline Emp. Bah. Flex. & 5.646 & 87 & 13 & 89 & 11 & 86 & 14 \\
\hline Over-Time Work & 4.747 & 65 & 35 & 71 & 29 & 67 & 33 \\
\hline Shift Work & 4.802 & 61 & 39 & 52 & 48 & 69 & 31 \\
\hline Contract Work & 5.591 & 81 & 19 & 81 & 19 & 81 & 19 \\
\hline Work-Life Balance & 6.250 & 92 & 8 & 90 & 10 & 94 & 6 \\
\hline
\end{tabular}

Source: Primary data, September (2019)

Descriptive Statistics of HR Flexibility. This research applied quantitative survey approach to analyse the key variable of the study whose items were some adopted, modified (e.g. Ketkar \& Sett 2009and Bhattacharya, Gibson \& Doty, 2005) and the rest developed following Hinkin (1998) six stages of questionnaire scale development with the aid of expert assessment and confirmation process.
The questionnaire used 7-point Likert scale as the instrument to gather data with a neutral mid-point. The questionnaire helps to assess the perception of the senior HR personnel representing the views of the organisations. All the items were answered starting with the highest value score of 7 as (strongly agree); 6 (agree); 5 (somewhat agree); 4 (undecided); 3 (somewhat disagree); 2 (disagree) and 1 (strongly disagree) as the 
least score value. The scales $1,2 \& 3$ are categorized as negative responses, score 4 is neutral whereas scores 5, $6 \& 7$ are registered as positive responses from the respondents. The construct demonstrated a satisfactory average variance extracted (.52), with a satisfactory Cronbach's Alpha coefficient of (.65). The composite reliability is satisfactory at (.81) and item loadings are satisfactory ranging from .67 to .83 .

The value HR flexibility in the organisation is the subject of scrutiny. HR flexibility comprises of 6 dimensions and include employee skill flexibility, employee behaviour flexibility, overtime work, shift work, contract work and work-life balance. From Table 2 above the results indicate differences in perception based on the responses from the participants. All the dimensions scored favourably well except for over-time work and shift work that received strong negative reception from the participants in the survey which is quite telling. Both the private and public organisations demonstrated similar negative responses. Work-life balance as a dimension stood out favorably with strong positive response from both public and private organisations.

The overall score for the HR flexibility construct shows that public organisations favourably edge private organisation with a descriptive statistic of $77 \%$ for public organisations and $74 \%$ for private organisations. This is significant for the fact that the two outstanding constructs for HR flexibility, employee skill flexibility and work-life balance favourably appealed to public organisations according to reports from senior HR personnel who participated in the survey. In the Gambia, public organisations engages in long-term training and development compared to private. Additionally, public organisations in the Gambia are more tolerant towards work-life balance as a HR flexibility e.g. 'sabbatical leave, leave of absence, sick leave, annual leave, maternal and paternal leave facilities' compared to private organisations.

Discussion. This section of the report is to answer " $R Q$ : what is the value of $H R$ flexibility to both the employer and employee?" and is divided into two parts. Firstly, addressed certain questions lifted from the questionnaire that specifically relates benefits of human resource flexibility in the organisation. The views expressed belong to senior HR personnel representing the views of their respective organisations. Secondly, a total of ten employees ( 8 public and 2 private) randomly chosen from among the 40 organisations that participated in the survey to represent the position of the employees.

From Table 3 above, relates to "employee skill flexibility benefits the organisation”. The table indicates that $95 \%$ of the participants positively recognised that employee skills flexibility benefits the organisation and only $5 \%$ representation rejected the statement. The high approval rating from the senior HR personnel established the fact that skill flexibility is an asset for organisation and enables the organisation to benefit from the diverse skill sets of the employees. The high support percentage is validated by the interview data. The results no doubt indicated that both organisations benefit immensely from employee skill flexibility with private organisations $92 \%$ approval response and $98 \%$ approval response for public 
organisations. Lepak et al. (2003), organisation's extensive reliance on knowledgebased employment is beneficial to organisational performance.

Employee skills flexibility affects and benefits me as it enables me to acquire skill diversity. I started work at procurement, but I am now moved to finance because of my training in finance. With skills flexibility, it would enable me to do many things as I was allowed to develop myself with support from the organisation (Informant 1, 2019).

Table 3

Employee Skill Flexibility

\begin{tabular}{|c|c|c|c|c|c|c|c|}
\hline \multicolumn{8}{|c|}{ Employee skill flexibility benefits the organisation } \\
\hline & & Frequency & $\begin{array}{l}\text { Valid } \\
\text { Percent }\end{array}$ & \multicolumn{2}{|c|}{ Private $\%$} & \multicolumn{2}{|c|}{ Public $\%$} \\
\hline \multirow[t]{5}{*}{ Valid } & Undecided & 4 & 5.0 & & 8.8 & & 2.2 \\
\hline & somewhat agree & 5 & 6.3 & & 8.8 & & 4.3 \\
\hline & Agree & 44 & 55.0 & & 44.1 & & 63.0 \\
\hline & strongly agree & 27 & 33.8 & & 38.2 & & 30.4 \\
\hline & Total & 80 & 100.0 & & 100.0 & & $\begin{array}{r}100 . \\
0\end{array}$ \\
\hline Missing & System & 22 & & $92(+)$ & $8(-)$ & $\begin{array}{l}98 \\
(+)\end{array}$ & $2(-)$ \\
\hline Total & & 102 & & & & & \\
\hline
\end{tabular}

Source: Primary data, September 2019

Table 4

Employee Behaviour Flexibility

\begin{tabular}{|c|c|c|c|c|c|c|c|}
\hline \multicolumn{8}{|c|}{ Flexibility of employees' work habits help us to change according to market demands } \\
\hline & & Frequency & $\begin{array}{c}\text { Valid } \\
\text { Percent }\end{array}$ & & ate $\%$ & \multicolumn{2}{|c|}{ Public \% } \\
\hline \multirow[t]{8}{*}{ Valid } & strongly disagree & 1 & 1.3 & & 2.9 & & 00 \\
\hline & Disagree & 5 & 6.3 & & 2.9 & & 8.7 \\
\hline & somewhat disagree & 1 & 1.3 & & 00 & & 2.2 \\
\hline & Undecided & 6 & 7.5 & & 11.8 & & 4.3 \\
\hline & somewhat agree & 19 & 23.8 & & 26.5 & & 21.7 \\
\hline & Agree & 29 & 36.3 & & 29.4 & & 41.3 \\
\hline & strongly agree & 19 & 23.8 & & 26.5 & & 21.7 \\
\hline & Total & 80 & 100.0 & & $\begin{array}{r}100 . \\
0\end{array}$ & & $\begin{array}{r}100 . \\
0\end{array}$ \\
\hline Missing & System & 22 & & $\begin{array}{l}82 \\
(+)\end{array}$ & $18(-)$ & $\begin{array}{l}85 \\
(+)\end{array}$ & $15(-)$ \\
\hline Total & & 102 & & & & & \\
\hline
\end{tabular}

Source: Primary data, September 2019

Table 4 relates to 'employees' work habits helps us change according to market demand". A total of $84 \%$ of the participants positively agreed that employee behaviour flexibility helps the organisation to change based on market demand. The strong approval from the senior HR personnel has been supported by some employees interviewed. The essence of this argument is that environmental conditions dictate the behavioural index of the employees. Above $80 \%$ positive approval response from both organisations shows that flexibility of employees work habits relates to the market 
demands for the organisation. This implies that employee's flexibility helps the organisation to easily adopt and relate to any changing situation. According to Lepak et al. (2003); Wright \& Snell (1998), the core benefit of resource flexibility is the ability to cope with various environmental and market demands placed on employees to help organisation prevail.

Behaviourally employees are vulnerable to the demands of the organisation. Employees have no other choice but to succumb. It is widely a debatable concern when addressed from the lens of ethics, below is the excerpts from the interview.

My appointment letter said it all, "any other duties and responsibilities that may be assigned to you". I regularly stay longer than the normal working hours waiting for my colleague to relieve me. I always have to stay around until hel she comes, and I will not be compensated for the extra hours spent waiting. Sometimes my colleague could get sick, I have no choice but to stay to fill the void (Informant 6, 2019).

Table 5

Shift Work

\begin{tabular}{|c|c|c|c|c|c|}
\hline \multicolumn{6}{|c|}{ Shift Work benefits the organisation } \\
\hline & & Frequency & $\begin{array}{l}\text { Valid } \\
\text { percent }\end{array}$ & $\begin{array}{l}\text { Private } \\
\%\end{array}$ & $\begin{array}{l}\text { Public } \\
\%\end{array}$ \\
\hline \multirow[t]{8}{*}{ Valid } & $\begin{array}{l}\text { strongly } \\
\text { disagree }\end{array}$ & 3 & 3.8 & 2.9 & 4.3 \\
\hline & disagree & 7 & 8.8 & 8.8 & 8.7 \\
\hline & $\begin{array}{l}\text { somewhat } \\
\text { disagree }\end{array}$ & 2 & 2.5 & 2.9 & 2.2 \\
\hline & undecided & 11 & 13.8 & 23.5 & 6.5 \\
\hline & $\begin{array}{l}\text { somewhat } \\
\text { agree }\end{array}$ & 7 & 8.8 & 5.9 & 10.9 \\
\hline & agree & 35 & 43.8 & 35.3 & 50.0 \\
\hline & $\begin{array}{l}\text { strongly } \\
\text { agree }\end{array}$ & 15 & 18.5 & 20.6 & 17.4 \\
\hline & Total & 80 & 100 & 100 & 100 \\
\hline Missing & System & 22 & & $62+/ 38-$ & $78+/ 22-$ \\
\hline Total & & 102 & & & \\
\hline
\end{tabular}

Table 5 relates to "shift work the benefits shift the organisation". A total of $70.1 \%$ participants agreed with the statement while $29.9 \%$ disagreed. The high positive response means that participants believed shift work benefits the organisation structuring work to boost production or service delivery to meet the different customer needs. Without doubt, shift work serves the organisation compared to the employees. A total of $62 \%$ respondents for the private organisations agreed that shift work benefits the organisation while for public organisation, $78 \%$ of the participants agreed with the statement, See the table for details. 
Shift work is available at operations, it is challenging for some especially during periods of festivities or problems that needed attention. Sometimes arrangement with colleagues can help but without one, it becomes frustrating to the person. (Informant 5,2019 ).

Table 6

Contract Work

\begin{tabular}{|c|c|c|c|c|c|c|c|}
\hline \multicolumn{8}{|c|}{$\begin{array}{l}\text { Temporary contract benefits the organisation by removing unproductive or } \\
\text { critical employees }\end{array}$} \\
\hline & & $\begin{array}{c}\text { Frequenc } \\
y\end{array}$ & $\begin{array}{c}\text { Valid } \\
\text { Percen } \\
t\end{array}$ & \multicolumn{2}{|c|}{ Private Org } & \multicolumn{2}{|c|}{ Public Org } \\
\hline \multirow[t]{8}{*}{ Valid } & $\begin{array}{l}\text { strongly } \\
\text { disagree }\end{array}$ & 1 & 1.3 & & 00 & & 2.2 \\
\hline & disagree & 9 & 11.3 & & 8.8 & & 13.0 \\
\hline & $\begin{array}{l}\text { somewhat } \\
\text { disagree }\end{array}$ & 7 & 8.8 & & 8.8 & & 8.7 \\
\hline & undecided & 9 & 11.3 & & 8.8 & & 13.0 \\
\hline & $\begin{array}{l}\text { somewhat } \\
\text { agree }\end{array}$ & 14 & 17.5 & & 17.6 & & 17.4 \\
\hline & agree & 24 & 30.0 & & 23.5 & & 34.8 \\
\hline & strongly agree & 16 & 20.0 & & 32.4 & & 10.9 \\
\hline & Total & 80 & 100.0 & & 100.0 & & 100. \\
\hline $\begin{array}{l}\text { Missin } \\
\mathrm{g}\end{array}$ & System & 22 & & 74(+ & $26(-)$ & 63(+ & $37(-)$ \\
\hline Total & & 102 & & & & & \\
\hline
\end{tabular}

Source: Primary data, September 2019

Table 6 relates to "contract bene-fits the organisation by removing unprodu-ctive or critical employees". A total positive response of $67.5 \%$ established that manage-ment agenda of instituting a temporary work contract benefits the organisation against the wish of most employees. while $32.5 \%$ rejected the proposition. Without doubt as reiterated by some employees interviewed, contract work arrangement goes against the wishes of the employees who always want secure longterm jobs. Some claimed for the abolition of contract work arrangement to give employee tenure of service.

A total of $74 \%$ agreed with the statement for private organisations and $63 \%$ agreed for public organisations. This may be a measure of control and push for merit-based approach to rewards but may also increase internal organisational politics. Lepak et al. (2003), an organisation's reliance on both knowledgebased employment and contract work produce higher performance.

I fully remembered some lecturers' contracts were terminated because they were critical of the management. So, I can say, the contract is in place for management to punish and keep others in control about their mischiefs. (Informant 2, 2019).

Table 7 relates "employees are not fairly rewarded for overtime work". A total of $68.8 \%$ of the senior HR personnel positively approved the question, while $31.2 \%$ negatively rejected. This question is very important because the strong admission from senior HR personnel that employees are not 
fairly rewarded for overtime work is worrying. This is quite interesting but at the same time, the concern is validated from the employees interviewed. The senior HR personnel who participated in the survey representing both private and public organisations agreed with the statement for lack of fair reward for overtime work. Reward is very important to employee motivation and contingent work requires contingent reward. Failure to reward fairly contradicts both procedural and interactional justice doctrine of the organisation. Pandey \&Khare (2013), long hours of work is linked in difficulties to balance work, personal and family obligations.

Table 7

Over-Time Work

\begin{tabular}{|c|c|c|c|c|c|c|c|}
\hline \multicolumn{8}{|c|}{ Employees are not fairly rewarded for overtime work } \\
\hline & & Frequency & $\begin{array}{l}\text { Valid } \\
\text { Percent }\end{array}$ & Priv & e \% & Pub & $c \%$ \\
\hline \multirow[t]{8}{*}{ Valid } & $\begin{array}{l}\text { strongly } \\
\text { disagree }\end{array}$ & 4 & 5.0 & & 2.9 & & 6.5 \\
\hline & disagree & 10 & 12.5 & & 20.6 & & 6.5 \\
\hline & $\begin{array}{l}\text { somewhat } \\
\text { disagree }\end{array}$ & 3 & 3.8 & & 00 & & 6.5 \\
\hline & undecided & 8 & 10.0 & & 11.8 & & 8.7 \\
\hline & $\begin{array}{l}\text { somewhat } \\
\text { agree }\end{array}$ & 14 & 17.5 & & 17.6 & & 17.4 \\
\hline & agree & 27 & 33.8 & & 23.5 & & 41.3 \\
\hline & strongly agree & 14 & 17.5 & & 23.5 & & 13.0 \\
\hline & Total & 80 & $\begin{array}{r}100 . \\
0\end{array}$ & & $\begin{array}{r}100 . \\
0\end{array}$ & & $\begin{array}{r}100 . \\
0\end{array}$ \\
\hline $\begin{array}{l}\text { Missin } \\
\mathrm{g}\end{array}$ & System & 22 & & $65(+$ & $35(-)$ & $72(+$ & $28(-)$ \\
\hline Total & & 102 & & & & & \\
\hline
\end{tabular}

Source: Primary data, September 2019

Table 8

Work-Life Balance

\begin{tabular}{|c|c|c|c|c|c|c|c|}
\hline \multicolumn{8}{|c|}{ Organisation have a work-life balance policy } \\
\hline & & Frequency & $\begin{array}{l}\text { Valid } \\
\text { Percent }\end{array}$ & Priv & te $\%$ & Publ & c $\%$ \\
\hline & $\begin{array}{l}\text { Strongly } \\
\text { disagree }\end{array}$ & 00 & 00 & & 2.9 & & 6.5 \\
\hline & Disagree & 00 & 00 & & 8.8 & & 4.3 \\
\hline & $\begin{array}{l}\text { Somewhat } \\
\text { disagree }\end{array}$ & 00 & 00 & & 2.9 & & 2.2 \\
\hline & undecided & 2 & 2.5 & & 8.8 & & 8.7 \\
\hline & $\begin{array}{l}\text { somewhat } \\
\text { agree }\end{array}$ & 2 & 2.5 & & 23.5 & & 17.4 \\
\hline & Agree & 15 & 18.8 & & 29.4 & & 43.5 \\
\hline & strongly agree & 61 & 76.3 & & 23.5 & & 17.4 \\
\hline & Total & 80 & $\begin{array}{r}100 . \\
0 \\
\end{array}$ & & $\begin{array}{r}100 . \\
0\end{array}$ & & 100.0 \\
\hline $\begin{array}{l}\text { Missin } \\
\mathrm{g}\end{array}$ & System & 22 & & )$^{76(+}$ & $24(-)$ & $78(+)$ & $22(-)$ \\
\hline Total & & 102 & & & & & \\
\hline
\end{tabular}

Source: Primary data, September 2019 
Employees engaged in a face-to-face interview have a similar view with the statement below. "Overtime work is something that is not recognised at the here. I do sometimes stay extra hours and it happens at the end of every month when preparing salaries. Even Saturdays I have to work during the last days of every month. It has been like this for many years without compensation. It is tiring for me but what I can do, I only have to comply to serve the institution." (Informant 8, 2019).

Table 8 relates to "organisation has work-life balance policy". The outcome of this statement has a strong endorsement of about $97.5 \%$ from the participants. Work-life balance policies are highly recognised by most organisations and this argument is corroborated by the responses received from the employees interviewed. But notwithstanding, some private organisations are often reluctant to implement work-life balance policies due to their quest to profit making. The institutionalization of the work-life balance policy is a contentious issue for some organisations. The recognition of work-life balance translates to greater commitment, less work/family conflicts, less intention for employees to leave the organisation (Traynor, 1999).

I have worked for this organisation for ten years and I was able to go on leave for only two weeks that happens many years ago. Each time I write to request for leave, it will be turn down. This is very unfair to me and I have never been compensated for it. HR does not care about the wellbeing of the employees instead side with management. I am tired and need rest, (informant 3, 2019).

\section{CONCLUSIONS}

The study report objectively addressed the question with mixed response on benefits from both public and private organisations in the Gambia. Employees believed that a secure job translate into financial security and social security for them and their families. This belief has strong effect on their attitude and behaviour and in their relationship with the organisation.

The study discovered 'Nepotism and Acting job portfolios' are new forms of work flexibility as numerated by some informants. This is a concern and will go long way to affect future viabilities of both organisations if not addressed on time. The diminishing roles of both the labour department and the office of the Ombudsman in the activities and relationship between organisations and employees. Employees are vulnerable to HR flexibilities when the organisation is financially struggling most especially employee in the gig economy.

The outcome of the research has shown that the views expressed by the Senior HR personnel may not entirely represent the position of the employees. Future research is recommended on a large scale to be equally representative both lower and upper level employees. A new research is recommended into acting jobs or position to help determined how it fits into HR flexibility and the strategy of the organisation. The study should be assessed in light of its limitations.

\section{REFERENCE}

Bhattacharya, M., Gibson, D. E., \& Doty, D. H. (2005). The effects of flexibility in employee skills, employee behaviour and HR practices 
on the firm performance. Journal of Management, 31, 622-640

Barney, J. B. (2001). Resource-based theories of Competitive Advantage: A ten-year retrospective on the resource-based view, Journal of Management, 27, 643-650

Blyton, P. (1992). Flexible times? Recent developments in temporal flexibility. Industrial Relations Journal, 23, 26-36

Carvalho, A., \& Cabral-Cardoso, C. (2008). Flexibility through HRM in management consulting firms. Personnel Review, 37, 332349

Fahlbeck, R. (1998). "Towards a revolutionized working life. The information society and the transformation of the workplace. The International Journal of Comparative labour law and Industrial Relations, 14, 247-265

Grenier, J. N., Giles, A., \& Belanger (1997). "Internal versus External Labour Flexibility: A Two-Plant Comparison in Canadian Manufacturing", Industrial Relations, 52, (4), 683-711

Guest, D. E., Michie, J., Conway, N., \& Sheehan, M. (2003). Human resource management and corporate performance in UK. The British Journal of Industrial relations, 41, 291-314

Hinkin, T., R. (1998). A Brief Tutorial on the Development of Measures for use in Survey Questionnaires, Organisational Research Methods, 2, (1), 104-121

Hitt, M. A.,Keats B W.,\& DeMarie, S. M. (1998). Navigating in the new competitive landscape: Building strategic flexibility and competitive advantage in the 21 st century, Academy of Management Executive, 12, (4)

Kallerberg, A. L, (2001). organising Flexibility: The Flexible Firm in a New Century, British Journal of Industrial Relations, 39, (4), 479504

Ketkar, S., \& Sett, P. K. (2009). HR Flexibility and firm performance: Analysis of a multilevel causal model. The International Journal of Human Resource management, 20, (5), 1009-1038

Lepak, D. P., Takeuchi, R., \& Snell, S. A. (2003). Employment flexibility and firm performance: Examining the interaction effects of employment mode, environmental dynamism and technological intensity, Journal of Management, 29, 681-703

MacDuffie, J. P. (1995). Human resource bundles and manufacturing performance: Organisational logic and flexible production system in the world auto Industry. Industrial and Labour Relations Review, 48, 197-221.

Martínez-Sánchez, A.,Vela-Jiménez M.,LuisCarnicer P., \& Pérez-Pérez M. (2007). Managerial perceptions of workplace flexibility and firm performance, International Journal of Operations \& Production Management, 27, (7), 714-734

Ngo, H., \& Loi, R. (2008). Human resource flexibility, organisational culture and firm performance: An investigation of multinational firms in Hong Kong, The International Journal of Human Resource Management, 19, 1654-1666

Pandey, J., \& Khare, R. (2013). Work-life balance practices and its impact on employee performance: A study of service organisations. Indian Journal of Health and Wellbeing, 4, 531-535

Pfeffer, J., Hatano, T., \& Santalainen, T. (1995). Producing sustainable competitive advantage through the effective management of people. The Academy of Management Executive, 9, 55-72

Roca-Puig et al. (2008). External and Internal labor Flexibility in Spain: A Substitute or complementary Effect, The International Journal of Human Resource Management, 19, (6), 1131-1151

Sekaran, U. \& Bougie, R. (2016), Research Methods for Business: A Skill-Building Approach, Seventh Edition, Wiley, West Sussex, UK. 
Sheridan, A., \& Conway, L. (2001). Workplace flexibility: Reconciling the needs of employers and employees. Women in Management Review, 16(1), 5-11

Traynor, J. B. (1999). Total life Planning: A New Frontier in Work-Life Benefits, Employee Benefits Journal, 24(4), 29-32

Upton, D. M. (1995). Flexibility as Process Mobility: The management of Plant
Capabilities for Quick Response Manufacturing, Journal of Operations Management, 12, 205-224

Wright, P. M., \& Snell, S. A. (1998). Toward a unifying framework for exploring fit and flexibility in strategic human resource management. The Academy of Management Review, 23, 756-772 